
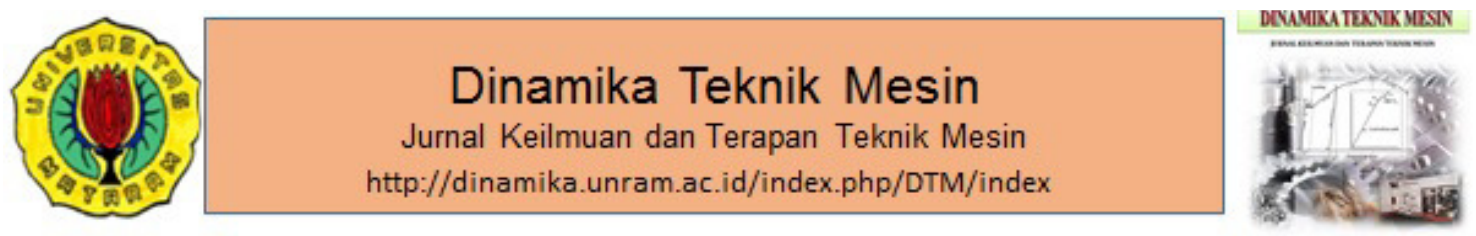

\title{
Peningkatan kekerasan dan ketahanan korosi paduan Fe-2,9Al-0,4C dengan proses karburisasi padat
}

\section{Increased Hardness and Corrosion Resistance of Fe-2.9Al-0.4C by Solid Carburization Process}

\section{R. Kartikasari ${ }^{\star}$ A. Susiana, D. Ocktavian}

Program Studi Teknik Mesin, Fakultas Teknologi Industri, Institut Teknologi Nasional Yogyakarta, Jl. Babarsari no. 1, Caturtunggal, Depok, Sleman, Yogyakarta 55281

"E-mail: ratna@itny.ac.id

\section{ARTICLE INFO}

Article History:

Received 08 February 2020

Accepted 13 January 2021

Available online 01 April 2021

\section{Keywords:}

Fe-2.9Al-0.4C alloy

Solid carburization

Microstrusture

Hardness

Corrosion resistance

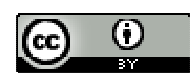

\section{ABSTRACT}

Fe-Al-C alloy is a superior and economical new alloy to replace the ferritic stainless steel, whereas aluminum replaces chromium, which is relatively expensive. Some applications of $\mathrm{Fe}-\mathrm{Al}-\mathrm{C}$ alloys require hardness at the surface. This study aims to determine the effect of the temperature carburizing process on the hardness and corrosion resistance of $\mathrm{Fe}-2,9 \mathrm{Al}-0,4 \mathrm{C}$ alloys. Material used is Fe-2,9Al-0,4C steel alloy. Surface hardening using a solid carburizing method. The solid carburizing process carried out by the holding time for 3 hours at various temperatures of $850^{\circ} \mathrm{C}, 900^{\circ} \mathrm{C}, 950^{\circ} \mathrm{C}, 1000^{\circ} \mathrm{C}$, and $1050^{\circ} \mathrm{C}$. Carburized is used in the form of powder coal and MgCO3 catalyst. Tests carried out are chemical composition, microstructure, hardness, and corrosion tests. The test results show that the chemical composition of the Fe-2,9Al-0,4C alloy contains elements of $2.91 \% \mathrm{Al}$ and $0.40 \% \mathrm{C}$. Microstructure formed is ferrite and pearlite with a dendritic pattern. The martensitic structure formed at $950^{\circ} \mathrm{C}, 1000^{\circ} \mathrm{C}$, and $1050^{\circ} \mathrm{C}$. The Carburizing process increases the hardness value where the higher temperature carburizing process, the higher hardness values until it reaches a maximum temperature of $1050^{\circ} \mathrm{C}$ with a hardness value of $1040.5 \mathrm{~kg} / \mathrm{mm} 2$. The highest corrosion resistance value occurs after the $850^{\circ} \mathrm{C}$ carburizing process at a rate of $41.58 \mathrm{mpy}$ corrosion (up $40.9 \%$ of the raw material). At a higher temperature carburizing process lowers the corrosion resistance of the alloy Fe-2,9Al-0,4C. 
Dinamika Teknik Mesin. Kartikasari dkk.: Peningkatan kekerasan dan ketahanan korosi paduan Fe-2,9Al-0,4C dengan proses karburisasi padat

\section{PENDAHULUAN}

Baja merupakan paduan yang terdiri atas besi, karbon, dan unsur paduan lainnya yang ditambahkan untuk mendapatkan sifat-sifat khusus. Stainless steel atau biasa disebut dengan baja tahan karat adalah salah satu dari jenis logam yang memiliki ketahanan korosi yang baik saat ini. Material jenis ini secara luas digunakan di banyak industri karena sifatnya yang kuat dan tahan korosi (Sulaiman dkk, 2016).

Penggunaanferritic stainless steel paduan $\mathrm{Fe}-\mathrm{Cr}-\mathrm{C}$ pada kehidupan manusia sudah di aplikasikan pada berbagai macam peralatan. Akan tetapi, dengan karakter yang dimilikinya, perlu dilakukan modifikasi untuk meningkatkan kekerasan maupun ketahanan korosinya. Pada penelitian ini modifikasi yang dilakukan adalah dengan mengganti paduan $\mathrm{Fe}-\mathrm{Cr}-\mathrm{C}$ dengan $\mathrm{Fe}-2,9 \mathrm{Al}-0,4 \mathrm{C}$ dimana unsur $\mathrm{Cr}$ (chrom) digantikan oleh unsur Al (aluminium). Baja paduan berbasis Fe-Al menarik banyak perhatian karena sifatnya yang luar biasa yaitu untuk aplikasi struktur pada temperatur tinggi. Densitasnya lebih rendah dibandingkan dengan material lainnya seperti besi cor dan baja tahan karat, ketahanan korosi yang baik pada suhu tinggi, tahan aus dan harganya yang murah. Karena harganya yang murah, baja jenis ini menjadi material alternatif yang potensial untuk menggantikan baja tahan karat konvensional (Peng dkk, 2019).

Baligidad dkk. (2007), melaporkan bahwa paduan Fe-10,5Al-0,7C mempunyai keuletan dan katangguhan yang rendah. Sementara itu Kobayashi dkk. (2005) dan Jablonska dkk. (2006) mengatakan bahwa paduan Fe-Al-C dikembangkan untuk aplikasi struktur hingga temperatur $873^{\circ} \mathrm{K}$. Giza dkk. (1999) melaporkan hasil penelitiannya bahwa paduan Fe-Al-C mempunyai ketahanan korosi yang baik dalam lingkungan netral tetapi terkorosi dengan cepat setara dengan besi tuang putih dalam lingkungan asam. Berbagaiupaya dilakukan untuk meningkatkan karakteristik paduan baru ini. Frommeyer (2000) melaporkan hasil penelitiannya yaitu bahwa penambahan Mn dalam sistem paduan Fe-Al akan menstabilkan struktur austenit dan akan dihasilkan paduan yang mempunyai hot workability dan keuletanyang baik. Rao (2004) menambahkan bahwa peningkatan kadar karbon dalam sistem Fe-Al-C dapat meningkatkan ketahanan oksidasi, tetapi efek negatif terjadi apabila peningkatan kadar karbon diikuti dengan penurunan kadar Al. Lebih jauh Baligidad (2007), melaporkan bahwa penambahan $2 \%$ unsur $\mathrm{Mn}$ dan Mo, dapat meningkatkan keuletan dan ketangguhan, sedangkan penambahan $2 \%$ unsur Si terbukti dapat meningkatkan kekuatan tarik paduan Fe-10,5Al-0,7C tetapi paduan menjadi sangat rapuh pada temperatur ruang.

Penambahan $\mathrm{Mn}$ bersama karbon (C) dalam paduan Fe-Al juga diyakini mampu memperluas dan menstabilkan daerah austenit, sehingga paduan yang dihasilkan akan mempunyai sifat-sifat mekanik yang baik pada temperatur tinggi (Banerji, 1982).Baja paduan Fe-Mn-Al-C dengan kandungan Al yang tinggi menawarkan kombinasi yang sangat baik untuk densitas massa yang rendah, meningkatkan ketahanan korosi, kekuatan yang tinggi dan keuletan yang baik (Seol, 2018).

Aplikasi baja paduan Fe-Al-C pada beberapa komponen seperti camp shaft,menyaratkan kekerasan permukaan dan ketahanan korosi yang tinggi. Sehingga perlu dilakukan proses perlakuan permukaan dan menurut Campagnolo dkk. (2019), beberapa dekade terakhir, perlakuan permukaan dan pelapisan telah dikembangkan pada komponen mekanis untuk beberapa kondisi seperti beban, keausan, dan korosi. Perlakuan permukaan dapat diklasifikasikan kedalam perlakuan permukaan mekanis (shot peening dan deep rolling), thermal(quenching dan tempering) dan difusi (carburizing, nitriding, carbonitriding dan nitrocarburizing). Karburisasi (carburizing) adalah proses termokimia (chemical heat treatment) permukaan baja dengan karbon sehingga atom karbon aktif akan berdifusi masuk ke permukaan baja. Tujuan utama dari proses karburisasi adalah untuk mendapatkan suatu permukaan yang keras dan tahan aus pada bagian-bagian mesin dengan menambahkan karbon pada lapisan permukaan (Ahmad, 2015). Berdasarkan sumber karbon, karburisasi diklasifikasikan karburasi padat (pack carburizing), karburisasi gas (gas carburizing), karburisasi cair (liquid carburizing) (Supriyono, 2018). Pack carburizing (karburasi padat) adalah proses penambahan unsur karbon ke permukaan logam, dimana sumber unsurkarbon dalam keadaan padat seperti arang, kokas, dan batubara, sehingga dapat meningkatkan angka kekerasan pada permukaan (Darmo dkk., 2018). Proses karburisasi padat merupakan proses karburisasi konvensional yang dapat dilakukan dengan mudah dan dengan biaya yang relative murah (Smith, 2002).

\section{METODE PENELITIAN}

Material yang digunakan dalam penelitian ini adalah coran paduan Fe-2,9Al-0,4C dalam bentuk ingot berukuran $30 \times 30 \times 200 \mathrm{~mm}$. Ingot paduanFe-2,9Al-0,4C sebelumnya dilakukan uji komposisi menggunakan spectrometer.Ingot ini selanjutnya dipotong benjadi berukuran $13 \times 13 \times 13 \mathrm{~mm}$ 
Dinamika Teknik Mesin. Kartikasari dkk.: Peningkatan kekerasan dan ketahanan korosi paduan Fe-2,9Al-0,4C dengan proses karburisasi padat

sebagai bahan yang akan dilakukan proses karburisasi. Carburizer yang digunakan adalah serbuk batu bara dan $15 \%$ katalis $\mathrm{MgCO}_{3}$. Proses karburisasidilakukan dengan metode karburisasi padat (pack carburizing)dimana carburizer yang berupa serbuk batubara dicampur dengan katalis MgCO3.

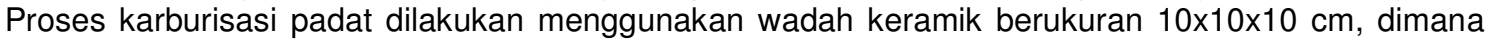
coran paduan $\mathrm{Fe}-2,9 \mathrm{Al}-\mathrm{C}$ dikemas diposisikan ditengah ruang dengan dikelilingicarburizer. Selanjutnya wadah yang sudah siap dengan specimen di dalamnya, dimasukkan ke dalam dapur dan dipanaskan pada temperatur austenit yangdivariasikanyaitu $850^{\circ} \mathrm{C}, 900^{\circ} \mathrm{C}, 950^{\circ} \mathrm{C}, 1000^{\circ} \mathrm{C}$, dan $1050^{\circ} \mathrm{C}$, masing-masingselama 3 jam dan dilanjutkan dengan pendinginan cepat dengan cara dicelup di dalam air. Setelah proses karburisasi spesimen dipotong melintang dan dilanjutkan dengan pengamplasan dan pemolesan untuk dilakukan analisis distribusi kekerasan dan pengujian struktur mikro. Spesimen uji struktur mikro terlebih dahulu dietsa menggunakan $\mathrm{HNO}_{3} \quad 0,5 \%$. Perubahan struktur mikro yang terjadi di amati menggunakan mikroskop optik pada tiga titik dari permukaan hingga ke dalam. Pengujian distribusi kekerasan spesimen terkarburisasi dilakukan dari permukaan ke dalam benda uji pada 10 titik uji. Pengujian korosi dilakukan dengan metoda kehilangan berat pada permukaan spesimen setelah dikarburisasi.Permukaan spesimen terlebih dulu diamplas dan dipoles permukaannya, kemudian ditimbang menggunakan timbangan digital selanjutnya direndam dalam larutan $\mathrm{HCl} 5 \%$ selama 100 jam, setelah perendaman spesimen dibersihkan dan ditimbang kembali untuk dicari selisih beratnya dan dihitung laju korosinya menggunakan rumus Fontana (1988).

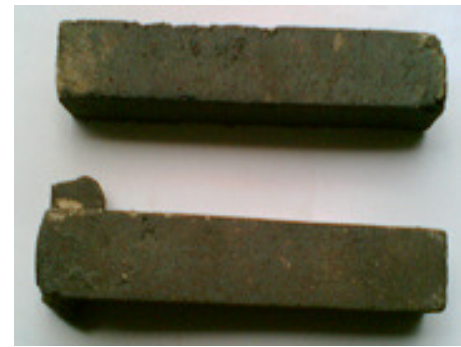

Gambar 1. Ingot coran paduan Fe-2,9Al-0,4C berukuran 30 × 30 × 200 mm
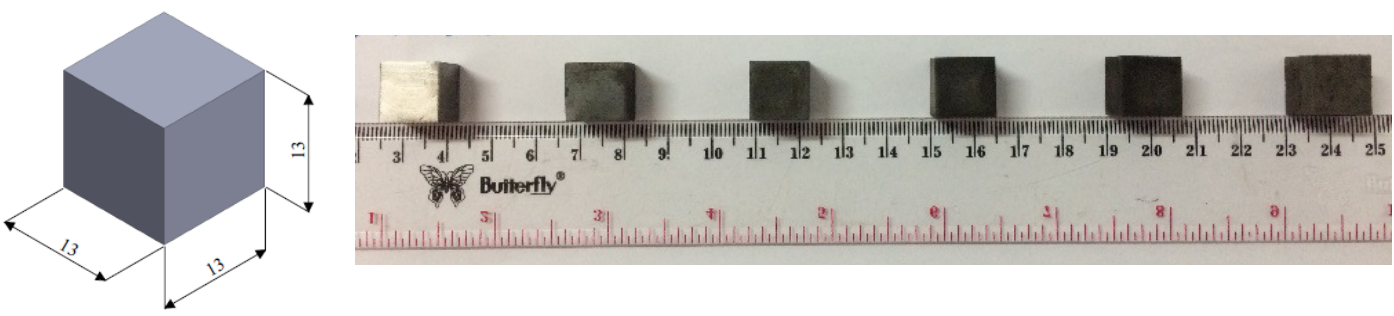

Gambar 2. Spesimen karburisasi paduan Fe-2,9Al-0,4C

\section{HASIL DAN PEMBAHASAN}

\subsection{AnalisisHasil Pengujian Komposisi Kimia}

Pengujiankomposisi kimia dilakukan untuk mengetahui unsur yang terkandung dalam spesimen paduan Fe-2,9Al-0,4C menggunakan alat uji spektrometer. Data hasil pengujian komposisi kimia paduan dapat dilihat pada Tabel 1.

Tabel 1 Hasil Pengujian Komposisi Kimia paduan Fe-2,9Al-0,4C

\begin{tabular}{llllllll}
\hline Unsur & $\mathrm{Fe}$ & $\mathrm{C}$ & $\mathrm{Al}$ & $\mathrm{Si}$ & $\mathrm{Mn}$ & $\mathrm{S}$ & $\mathrm{P}$ \\
\hline Kadar(\% berat) & 95,38 & 0,4 & 2,91 & 0,98 & 0,25 & 0,05 & 0,03 \\
\hline
\end{tabular}


Dinamika Teknik Mesin. Kartikasari dkk.: Peningkatan kekerasan dan ketahanan korosi paduan Fe-2,9Al-0,4C dengan proses karburisasi padat

Hasil pengujian komposisi kimia menunjukkan bahwa jumlah kandungan unsur dalam paduan Fe-2,9Al-0,4C adalah (Al) 2,91\%, dan (C) 0,40\%. Penambahan unsur (Al) sebesar 2,91\% berfungsi sebagai pembentuk dan penstabil struktur ferit (Frommeyer, 2000), serta dapat meningkatkan ketahanan korosi dan oksidasi. Unsur C yang cukup tinggi yaitu sebesar $0,40 \%$ mendorong terbentuknya struktur perlit yang akan meningkatkan kekerasan. Unsur Si yang jumlah kandungannya 0,98\% mampu menaikan tegangan tarik dan menurunkan laju pendinginan tetapi dalamjumlah yang besardapatmengurangi sifat kemagnetan pada paduan. Unsur-unsur yang lain jumlahnya sangat kecil sehingga tidak berpengaruh secara signifikan terhadap sifat paduan $\mathrm{Fe}-2,9 \mathrm{Al}-0,4 \mathrm{C}$. Baja paduan ini termasuk baja paduan menengah karena jumlah total kandungan unsur paduan sebesar $4,62 \%$.

\subsection{Analisis Hasil Pengujian Struktur Mikro}

Pengujian struktur mikro dilakukan menggunakan mikroskop optik pada bagian tepi yaitu sisi yang terdekat dengan permukaan, bagian transisi yaitu bagian antara tepi dan tengah, dan bagian tengah yaitu bagian tengah specimen, dari permukaan potong melintang spesimen setelah proses karburisasi. Pengujian struktur mikro dilakukan dengan perbesaran 100x, tujuannya adalah untuk mengetahui perubahan struktur mikro yang terjadi dari permukaan hingga bagian dalam akibat adanya difusi atom karbon ke dalam spesimen selama proses karburisasi. Spesimen uji terdiri atas spesimen raw material dan spesimen hasil proses karburisasi padat yang dilakukan dalam waktu tahan 3 jam dengan variasi temperatur $850^{\circ} \mathrm{C}, 900^{\circ} \mathrm{C}, 950^{\circ} \mathrm{C}, 1000^{\circ} \mathrm{C}$ dan $1050^{\circ} \mathrm{C}$. Hasil pengujian struktur mikro permukaan potong specimen hasil proses karburisasi dapat dilihat pada Gambar 3. Hasil pengujian struktur mikro pada Gambar 3a. menunjukkan bahwa paduan Fe-2,9Al-0,4C memiliki struktur ferit dan perlit. Terlihat jelas fungsi unsur Al sebagai pembentuk dan penstabil struktur ferit sehingga pada kadar $\mathrm{C}$ yang medium struktur ferit terlihat dominan, struktur perlit yang terlihat menunjukkan fungsi unsur $\mathrm{C}$ yang mendorong terbentuknya struktur perlit.
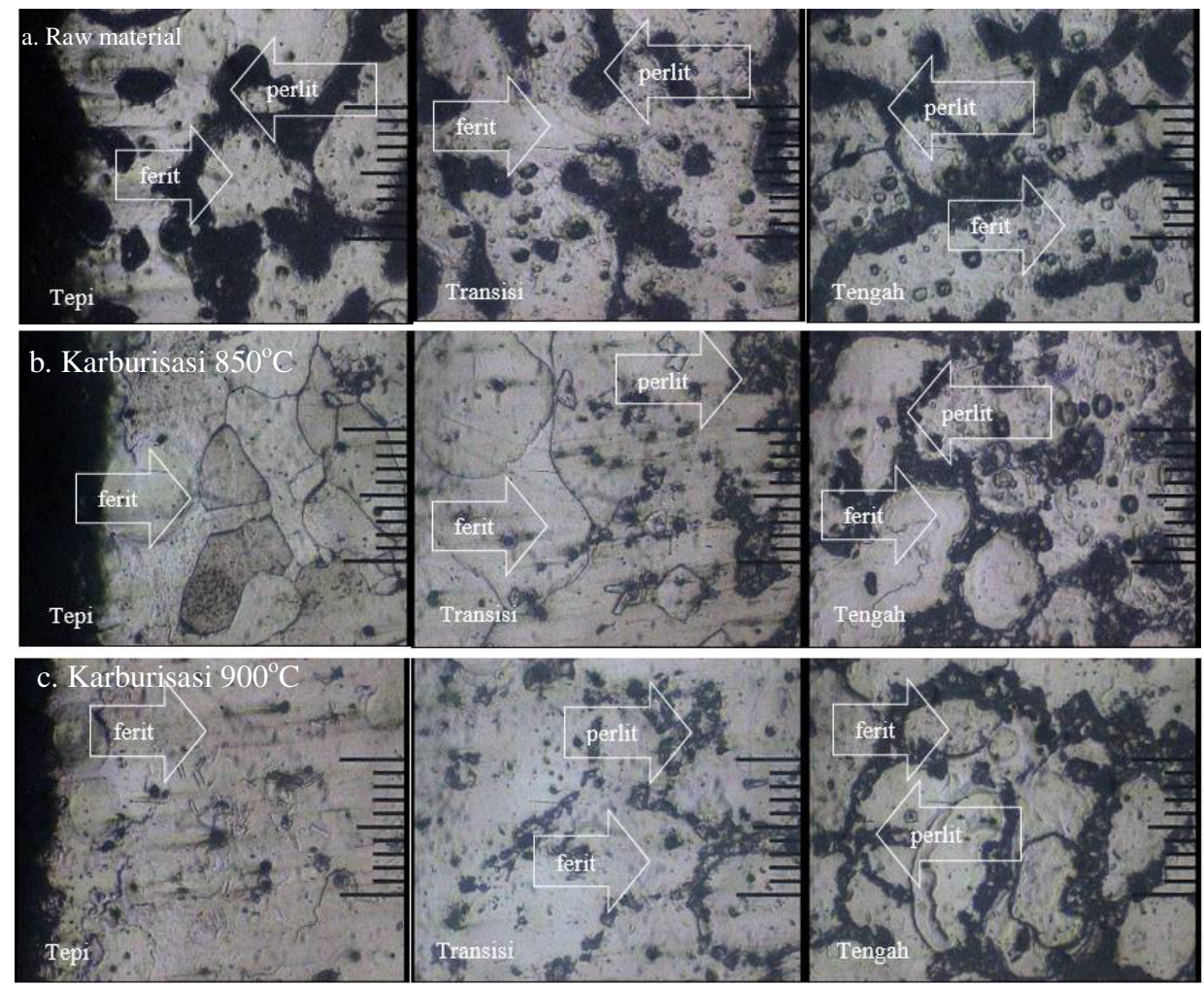

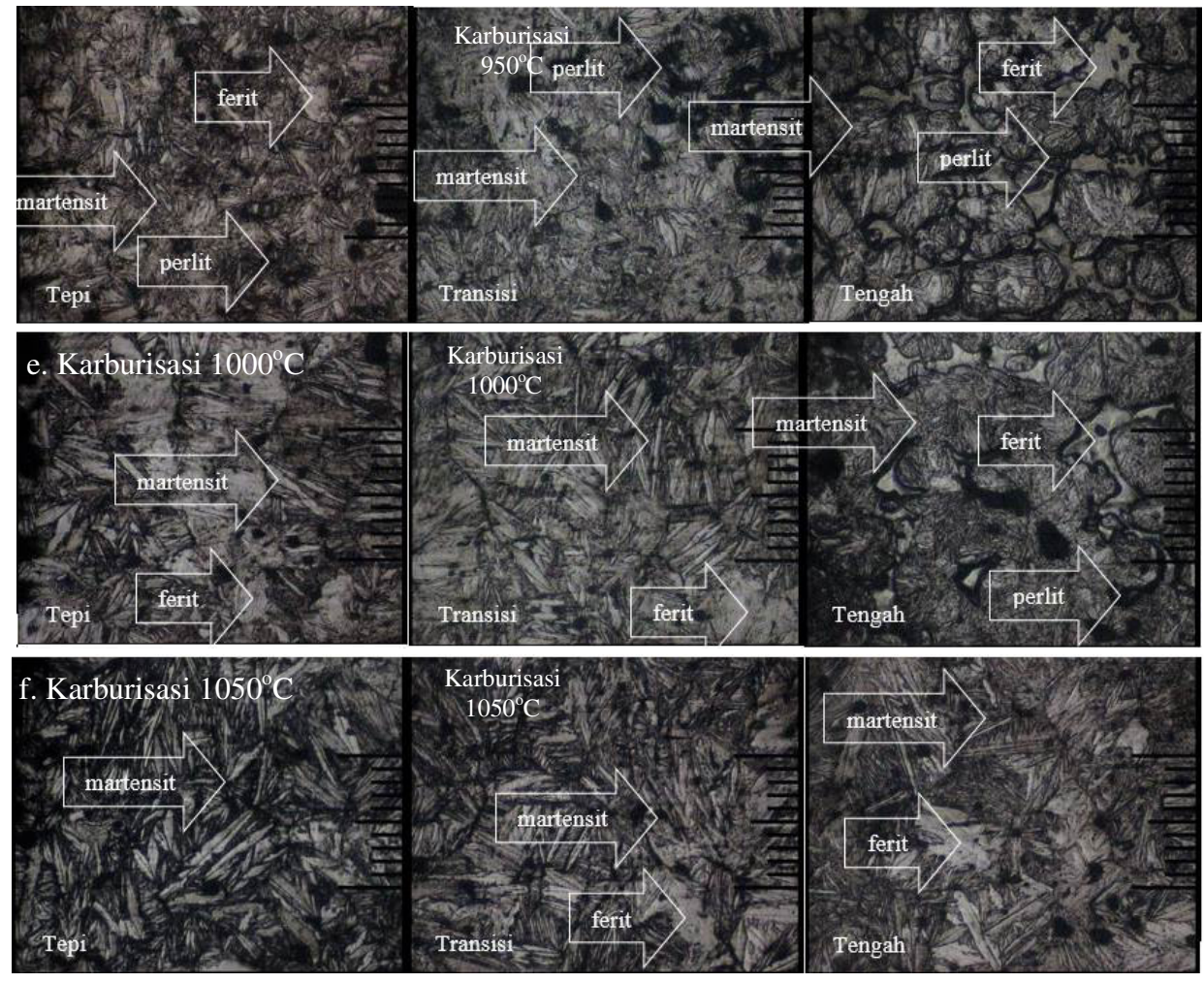

Gambar 3. Srtuktur mikro paduan Fe-2,9AI-0,4Csebelum dan sesudah proses karburisasi

Setelah proses karburisasi pada temperatur $850^{\circ} \mathrm{C}$ (Gambar $3 \mathrm{~b}$ ) terlihat bahwa pada permukaan hanya terlihat struktur ferit sedangkan struktur perlit tidak terlihat sama sekali. Pada bagian transisi mulai terlihat adanya struktur perlit di bagian yang lebih dalam. Semakin ke dalam struktur perlit semakin banyak. Pada temperatur ini belum terlihat munculnya struktur martensit yang diharapkan terbentuk di permukaan. Hal ini disebabkan proses austenitisasi paduan Fe-Al belum terjadi sehingga unsur karbon belum dapat terdifusi masuk ke permukaan paduan selama proses karburisasi. Disamping itu pada temperatur ini peruraian unsur karbon dari carburizer juga belum terjadi sehingga belum terlihat unsur karbon yang masuk ke permukaan paduan. Hal yang hampir sama terjadi pada karburisasi dengan temperatur $900^{\circ} \mathrm{C}$ (Gambar 3c), akan tetapi struktur perlit sudah terlihat lebih banyak terbentuk dan tersebar di batas butir pada bagian transisi dan tengah.

Struktur mikro hasil proses karburisasi pada temperatur $950^{\circ} \mathrm{C}$ (Gambar 3d) pada bagian permukaan terlihat sekali adanya struktur martensit yang mendominasi, sebagian kecil struktur ferit dan perlit, bahkan sampai bagian transisi. Hal ini menunjukkan austenitisasi sudah tercapai dan peruraian karbon pada carburizer juga sudah terjadi sehingga proses difusi karbon ke dalam baja paduan bisa berjalan sempurna selama proses karburisasi. Proses quenching merubah struktur perlit menjadi martensit. Peningkatan jumlah struktur martensit terus terjadi sampai dengan karburisasi pada temperatur $1050^{\circ} \mathrm{C}$ (Gambar $3 \mathrm{f}$ ), hal ini disebabkan atom karbon yang terdifusi ke dalam spesimen semakin banyak dan semakin dalam masuk ke dalam baja dengan semakin tinggi temperatur. Pada bagian tepi terlihat struktur martensit lebih padat dan dominan, di bagian transisi terlihat struktur martensit berkurang tetapi tidak signifikan demikian selanjutnya sampai bagian dalam. Hal ini menunjukkan atom karbon yang masuk ke dalam baja terdistribusi hampir merata semakin ke dalam terjadi pengurangan atom karbon tetapi tidak signifikan, semakin ke dalam struktur martensit masih terlihat dominan dengan butiran yang terlihat lebih besar. Hal ini disebabkan atom karbon membutuhkan energi yang lebih besar untuk menembus sampai ke dalam susunan atom-atom $\mathrm{Fe}$. Keberadaan unsur Al yang cukup tinggi diduga dapat meningkatkan difusifitas atom karbon sehingga dapat menyisip lebih dalam dan mendorong pembentukan karbida di permukaan. 
Dinamika Teknik Mesin. Kartikasari dkk.: Peningkatan kekerasan dan ketahanan korosi paduan Fe-2,9Al-0,4C dengan proses karburisasi padat

\subsection{Analisis Hasil Pengujian Distribusi Kekerasan}

Pengujian kekerasan pada setiap spesimen dilakukan menggunakan metode Micro Vickers sebanyak 5 titik pada permukaan dan 10 titik dari tepi ke tengah dengan jarak antar titik $0,5 \mathrm{~mm}$.

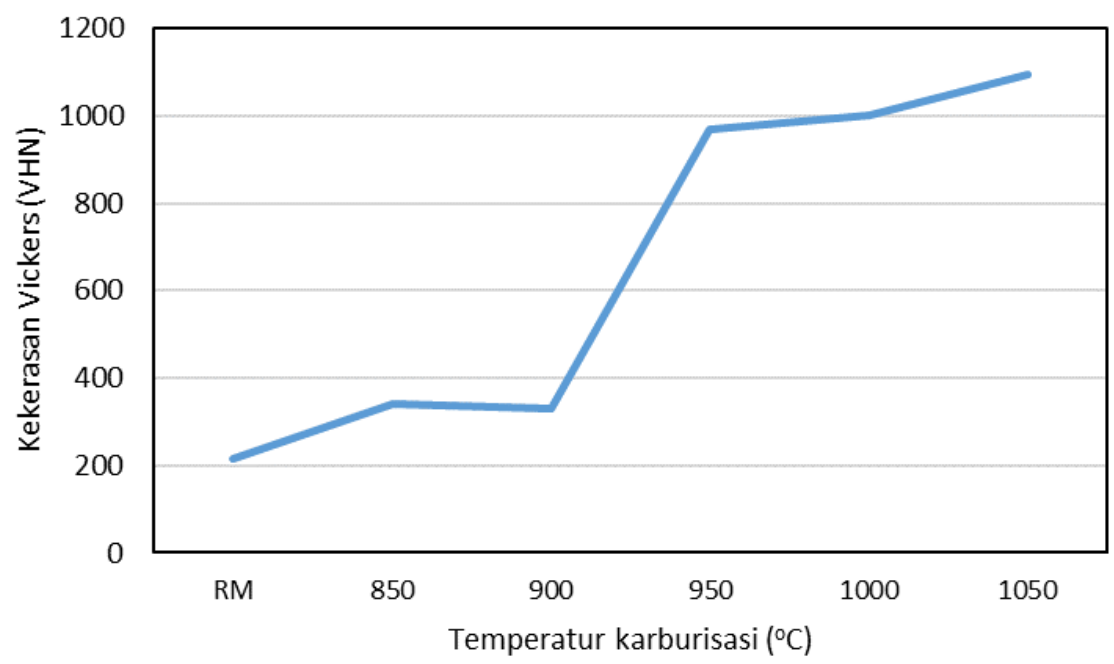

Gambar 4. Kekerasan permukaan paduan Fe-2,9AI-0,4C

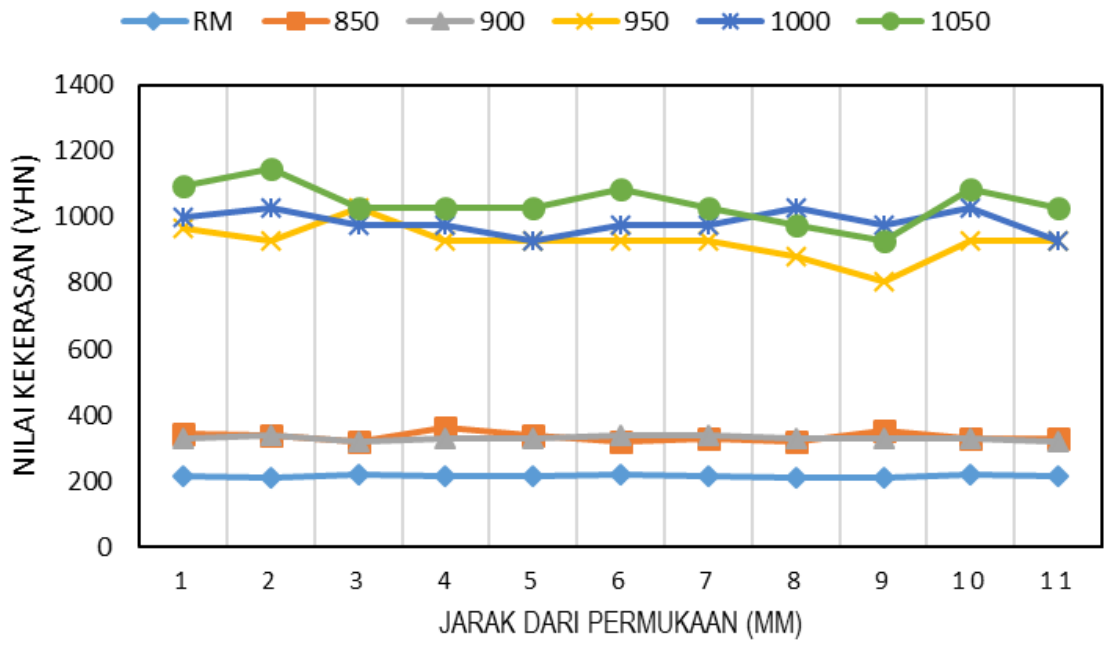

Gambar 5. Distribusi kekerasan paduan Fe-2,9Al-0,4C

Hasil uji kekerasan paduan Fe-2,9Al-0,4C (Gambar 4) menunjukkan bahwa harga kekerasan untuk spesimen raw material sebesar $215,3 \mathrm{~kg} / \mathrm{mm}^{2}$, dimana struktur mikro terdiri dari struktur ferit dan perlit dengan pola dendritik. Pada proses karburisasi $850^{\circ} \mathrm{C}$ dan $900^{\circ} \mathrm{C}$ terjadi peningkatan nilai kekerasan tetapi tidak signifikan, hal ini disebabkan struktur ferit dan perlit masih mendominasi belum terbentuk struktur martensit di pemukaan. Karena pada temperatur tersebut proses austenitisasi paduan $\mathrm{Fe}-2,9 \mathrm{Al}-0,4 \mathrm{C}$ belum terjadi, sehingga karbon (C) tidak dapat terdifusi masuk ke dalam $\mathrm{Fe}$. Pada proses karburisasi $950^{\circ} \mathrm{C}, 1000^{\circ} \mathrm{C}$, dan $1050^{\circ} \mathrm{C}$ terjadi peningkatan kekerasan yang signifikan,hal ini disebabkan karena pada temperatur ini terjadi prosesaustenitisasi pada paduan $\mathrm{Fe}$ 2,9Al-0,4C $\left(912^{\circ} \mathrm{C}-1394^{\circ} \mathrm{C}\right)$, sehingga atom karbon (C) dari batu bara terdifusi masuk ke dalam $\mathrm{Fe}$ dan ketika dilakukan proses quenching terbentuklah struktur martensit. Selain terbentuk struktur 
martensit unsur karbon (C) akan terikat pada Fe dan Al membentuk karbida Fe dan karbida Al yang menyebabkan terjadinya peningkatan kekerasan yang signifikan.

Keseluruhan data yang diperoleh menunjukkan bahwa semakin tinggi temperatur proses karburisasi harga kekerasan akan semakin meningkat. Hal ini disebabkan karena semakin tinggi temperatur maka jarak antar butir akan semakin besar, dimana unsur karbon (C) yang masuk juga akan semakin banyak. Spesimen yang mengalami perlakuan panas di temperatur austenisasi memiliki nilai kekerasan yang lebih besar daripada kekerasan spesimen yang mengalami perlakuan panas di bawah temperatur austenisasi. Hal tersebut disebabkan karena struktur martensit lebih mendominasi, sehingga nilai kekerasan meningkat. Nilai kekerasan yang semakin meningkat dengan perlakuan karburisasi dan quenching menunjukkan bahwa paduan Fe-Al 2,9-0,4C dapat dikeraskan (Kartikasari, 2015).

Hasil uji distribusi kekerasan (Gambar 5) menunjukkan bahwa pada specimen sebelum proses karburisasi dan setelah karburisasi pada temperatur $850^{\circ} \mathrm{C}$ dan $900^{\circ} \mathrm{C}$ tidak ada gradien nilai kekerasan dari permukaan sampai ke dalam, hal ini disebabkan belum terjadinya proses difusi karbon ke permukaan paduan $\mathrm{Fe}-2,9 \mathrm{Al}-0,4 \mathrm{C}$ sehingga tidak terbentuk martensit di permukaan. Proses karburisasi pada temperatur mulai $950^{\circ} \mathrm{C}$ sampai dengan $1050^{\circ} \mathrm{C}$ menyebabkan terjadinya peningkatan kekerasan di permukaan dan semakin ke dalam terjadi penurunan nilai kekerasan tetapi tidak signifikan. Hal ini menunjukkan bahwa difusi atom karbon ke dalam paduan terjadi secara maksimal sehingga kekerasan relatif sama di permukaan hingga ke dalam. Kenyataan ini juga diperkuat oleh hasil uji struktur mikro dimana struktur martensit hampir merata sampai ke dalam.

\subsection{Analisis Hasil Pengujian Korosi}

Pengujian korosi ini dilakukan menggunakan metode kehilangan beratdi dalam media larutan $\mathrm{HCl}$ dengan kadar 5\%. Spesimen direndam dalam larutan $\mathrm{HCl} 5 \%$ selama 100 jam, sebelumnya specimen ditimbang. Penimbangan dilakukan lagi setelah perendaman 100 jam dengan terlebih dahulu specimen dibersihkan menggunakan alkohol dan dikeringkan. Selisih berat sebelum dan sesudah perendaman menjadi dasar perhitungan laju korosi.

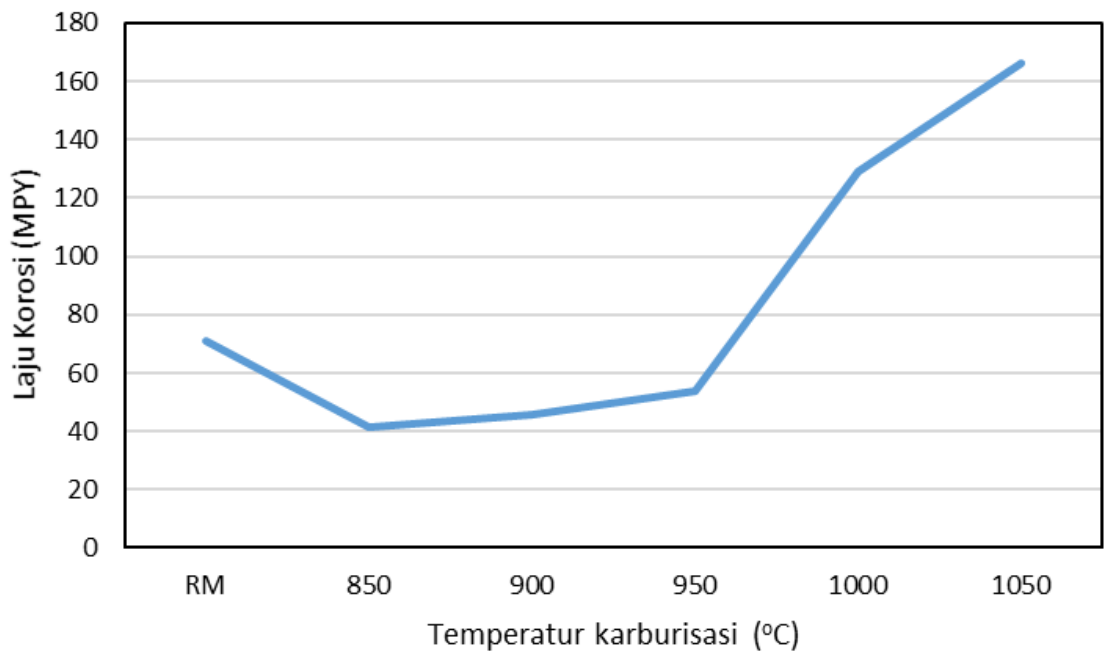

Gambar 6. Laju korosi baja paduan Fe-2,9Al-0,4C

Hasil uji korosi (Gambar 6) menunjukkan bahwa laju korosi terendah terjadi pada paduan Fe$2,9 \mathrm{Al}-0,4 \mathrm{C}$ setelah proses karburisasi pada temperatur $850^{\circ} \mathrm{C}$, semakin tinggi temperatur proses karburisasi laju korosi semakin meningkat dengan laju korosi tertinggi sebesar 166,3 MPY. Dengan kata lain ketahanan korosi tertinggi dicapai oleh paduan Fe-2,9Al-0,4C setelah proses karburisasi pada temperatur $850^{\circ} \mathrm{C}$ dengan laju korosi sebesar $41,58 \mathrm{MPY}$. Berdasarkan Tabel 2 laju korosi terendah termasuk dalam katagori cukup baik, sedangkan laju korosi tertinggi termasuk katagori kurang baik.

Proses karburisasi dapat menurunkan laju korosi raw material dari 70,68 MPY menjadi 41,58 MPY atau terjadi penurunan sebesar $40,9 \%$. Hal ini disebabkan terbentuknya lapisan oksida 
Dinamika Teknik Mesin. Kartikasari dkk.: Peningkatan kekerasan dan ketahanan korosi paduan Fe-2,9Al-0,4C dengan proses karburisasi padat

aluminium pada permukaan baja setelah karburisasi pada $850^{\circ} \mathrm{C}$ sehingga laju korosi terhambat (Kartikasari, 2014). Hal ini tidak terjadi pada saat unsur karbon sudah mulai masuk terdifusi ke permukaan baja dan membentuk struktur martensit. Struktur martensit menyebabkan laju korosi meningkat kembali bahkan sangat tinggi hingga 134\%. Hal ini disebabkan internal stress yang terjadi pada sturktur martensit menjadi awal terjadinya korosi sekaligus mempercepat terjadinya proses korosi.

Tabel 2. Tingkat ketahanan korosi berdasarkan harga mpy

\begin{tabular}{cccccc}
\hline Tingkat & $\begin{array}{c}m p y \\
\text { ketahanan korosi }\end{array}$ & \multicolumn{4}{c}{ Konversi satuan lain } \\
\cline { 6 - 6 } & year $)$ & mm/tahun & $\mu /$ tahun & nm/tahun & pm/tahun \\
\hline Luar biasa & $<1$ & $<0,02$ & $<25$ & $<2$ & $<1$ \\
Sangat baik & $1-5$ & $0,02-0,1$ & $25-100$ & $2-10$ & $1-5$ \\
Baik & $5-20$ & $0,1-0,5$ & $100-500$ & $10-50$ & $5-20$ \\
Cukup baik & $20-50$ & $0,5-1$ & $500-1000$ & $50-150$ & $20-50$ \\
Kurang baik & $50-200$ & $1-5$ & $1000-5000$ & $150-500$ & $50-200$ \\
\hline
\end{tabular}

Sumber: Corrosion Engnineering, Fontana (1988)

\section{KESIMPULAN}

1. Hasil uji struktur mikro menunjukkan bahwa paduan $\mathrm{Fe}-2,9 \mathrm{Al}-0,4 \mathrm{Cmemiliki}$ struktur ferit dan perlit yang berpola dendritik. Struktur martensit mulai terbentuk di permukaan baja pada temperatur proses karburisasi $950^{\circ} \mathrm{C}$ dan semakin banyak hingga temperatur $1050^{\circ} \mathrm{C}$.

2. Hasil uji kekerasan menunjukkan paduan Fe-2,9Al-0,4C memiliki kekerasansebesar 215,3 VHN. Nilai kekerasan meningkat dengan proses karburisasi padat dimana nilai kekerasan tertinggi sebesar $1040,5 \mathrm{VHN}$ dicapai pada temperatur $1050^{\circ} \mathrm{C}$.

3. Hasil pengujian ketahanan korosi menunjukkan bahwa, raw material memiliki ketahanan korosi sebesar 70,68 mpy, ketahanan korosi paling tinggi terjadi pada proses karburisasi padat dengan temperatur $850^{\circ} \mathrm{C}$ yaitu sebesar $41,58 \mathrm{mpy}$ dan termasuk dalam katagori cukup baik. Semakin tinggi temperatur proses karburisasi ketahanan korosi semakin menurun.

\section{UCAPAN TERIMAKASIH}

Penulis pada kesempatan ini mengucapkan terimakasih kepada semua pihak yang telah berperan serta sehingga penelitian ini dapat diselesaikan. Penulis memberikan apresiasi khusus kepada Program Studi Teknik Mesin Institut Teknologi Nasional Yogyakarta yang telah memberikan dukungan penuh hingga terselesaikannya penelitian ini.

\section{DAFTAR PUSTAKA}

Ahmad J.K., 2015, Carburizing of steel, International Journal of Materials Science and Applications, 4 (2-1), 11-14.

Baligidad R.G., Prasad S.K., 2007, Effect of Al and C on structure and mechanical properties of Fe-Al$C$ alloys, Materials Science and Technology, 23(1), 38-44.

Baligidad R.G., Prasad S.K., Rao A., 2007, Effect of Ti, W, Mn, Mo, and Si on microstructure and mechanical properties of high carbon Fe-10,5wt\% Al alloy, Journal of Material Science and Technology, 23(5), 613-619.

Banerji S.K., 1982, The 1982 status report on Fe-Mn-Al steel, Foote Mineral Co, Exton.

Campagnolo A., Dabala M., Meneghetti G., 2019, Effect of salt bath nitrocarburizing and postoxidation on static and fatigue behaviour of a construction steel, Metals 2019, 9, 1306.

Darmo S., Soenoko R., Siswanto E., Widodo D.T., 2018, Study on mechanical properties of pack carburizing SS400 steel with energizer pomacea canalikulata lamarck shell powder, Internasional Journal Of Mechanical Engineering and Technology (IJMET), 9(5), 14-23.

Fontana G.M., 1988, Corrosion engineering, 3th ed., McGraw Hill Inc., Singapore.

Frommeyer G., 2000, Physical and mechanical properties of Iron-Aluminum-(Mn-Si) lightweight steels, The 1999 ATS International Steelmaking Conference, Paris. Sec.4. 
Dinamika Teknik Mesin. Kartikasari dkk.: Peningkatan kekerasan dan ketahanan korosi paduan Fe-2,9Al-0,4C dengan proses karburisasi padat

Giza K., Bala H., Wysocki J.J., Szymura S., 1999, Corrosion resistance of Fe-Al-C permanent magnet alloy, Intermetallic, 6(5),357-362.

Jablonska M., Jasik A., Hanc A., 2009, Structures and phases transitions of the alloys on the bases of Fe-Al intermetallic phases, International Scientific Journal, 29(1), 16-19.

Kobayashi S., Zaefferer S., Schneider A., Raabe D., Frommeyer G., 2005, Optimisation of precipitation for controlling recrystallization of wrought Fe3Al based alloys, Intermetallics, 13, 1296-1303.

Peng J., Moszner F., Rechmann J., Vogel D., Palm M., Rohwerder M., 2019, Influence of Al content and pre-oxidation on the aqueous corrosion resistence of binary Fe-Al alloys in sulphuric acid, Corrosion Science, 149, 123-132.

Rahnama A., Kotadia H., Clark S., Janik V., Sridar S., 2018, Nano-mechanical properties of Fe-MnAl-C lightweight steel, Scientific Reports, 8, 9065.

Kartikasari R., 2014, Effect of aluminum content on microstructure andcorrosion behavior of as cast Fe-Al-C alloys lightweightsteel, International Journal of Applied Engineering Research, 9 (13), 2241-2249.

Kartikasari R., 2015, Effect of mangan content on mechanical properties and corrosion behavior of as cast Fe-7.5Al-0.6C alloy, International Journal of Applied Engineering Research, 10(13), 32884-32887.

Seol J.B.,2018,A Brief review of K-carbide in Fe-Mn-Al-C model alloy, Applied Microscopy, 48(4);116121.

Rao S.V., 2004, High temperature oxidation behavior of Fe-Al-C alloys: an overview, Materials Science and Engineering. A, 364(1-2), 232-239.

Smith W.F., 2002, Structure and properties of engineering alloys, $2^{\text {nd }}$ ed., McGraw-Hill, Inc., New York.

Sulaiman S.A., Alias S.K., Ahmad S., Fauzi M.H., Ahmad N.N., 2016, Study on the effect of corrosion behaviour of stainless steel before and after carburizing heat treatment, Material Science and Engineering, 160, 012027.

Supriyono, 2018, The Effect of pack carburizing using charcoal on properties of mild steel, Media Mesin:Jurnal IImiah Teknik Mesin, 19(1), 38-44. 